\title{
COMBINED CALCULATION OF RADIATION FROM LARGE-SIZED GROUND RW STORAGE FACILITIES ON THE BASIS OF MONTE CARLO METHOD
}

\author{
V.G. Rudychev ${ }^{1}$, N.A. Azarenkov ${ }^{1}$, I.O. Girka ${ }^{1}$, D.V. Rudychev ${ }^{1}$, Y.V. Rudychev ${ }^{2}$ \\ ${ }^{I}$ V.N. Karazin Kharkiv National University, Kharkiv, Ukraine; \\ ${ }^{2}$ National Science Center "Kharkov Institute of Physics and Technology", Kharkiv, Ukraine \\ E-mail: rud@pht.univer.kharkov.ua
}

A technique to reduce the dose rates, produced by large-sized ground-based radiation sources with dozens of radiating elements of the same geometry arranged along the perimeter, is developed. The radiating elements represent the concrete rectangular casks into which cylindrical barrels filled with compacted RW are loaded. The spatial distribution of the radiation around the cask is calculated by the Monte Carlo method. The radiation is assumed to be produced by the definite radionuclides of RW. Shielding by neighboring containers and the presence of an additional biological shielding are taken into account. Different options of the container arrangement are considered.

\section{INTRODUCTION}

During operation of all the types of nuclear power plants (NPPs), liquid and solid radioactive waste (RW) is produced. For the long-term operation of NPPs in Ukraine, a significant amount of RW has been accumulated. To reduce the RW volume at the NPPs, it is preprocessed. The liquid waste is evaporated (it turns to "salt melt"), solid combustible waste is burned and pressed, non-combustible waste is pressed. The resulting conditioned RW is placed into cylindrical barrels with the volume of 200 to $280 \mathrm{l}$. One of the options for the further handling of the conditioned waste is loading it into the reinforced concrete rectangular casks, which either are transported to the permanent storage site or may be temporarily (up to 50 years) stored at the site area of the NPP. The RW storage efficiency is achieved at the capacity of over 1000 rectangular casks that can be arranged in several tiers [1].

Such a storage facility represents a radiation source with the size of tens of meters, consisting of radiating elements of the same geometry but of different activity and isotopic composition. Storage of the conditioned RW at the NPP site, whose area is limited, requires adherence to the radiation safety standards for the NPP personnel who are working at the territory adjacent to the storage facility. Ensuring the radiation safety standards is possible either by building up a protective wall of concrete around the storage site, or by making a disciplinary fence outside the security zone. One cannot calculate the external radiation, which varies both at sequential filling of the storage site and due to changes in the isotopic composition subject to the RW storage time, by traditional methods. The correct calculation of the radiation generated by only one rectangular cask, in which cylindrical barrels filled with conditioned RW are placed, is currently possible only by Monte Carlo methods.

The objective of this work is:

- to develop a combined method of calculation for the external radiation from a large source, consisting of radiating elements of the same geometry, on the basis of the calculation of the radiation from the reinforced concrete rectangular casks, loaded by barrels with RW of different activity and isotopic composition, by using the Monte Carlo method;

- to minimize the dose rates on the NPP personnel due to arranging the sources of different radiation dose along the storage area perimeter.

\section{INITIAL DATA}

At present, nonreturnable reinforced concrete protective casks (NCPC)-150-1.5P are used to pack up the conditioned radioactive waste [1]. The NCPC casks are designed for loading them with radioactive waste of low and intermediate level and its safe long-term storage. The shape and dimensions of the cask comply with the conditions of arrangement of four 200 literbarrels containing mainly "salt melt". Characteristics of the NCPC-150-1.5P are given in Table 1, and its outer view is shown in Fig. 1.

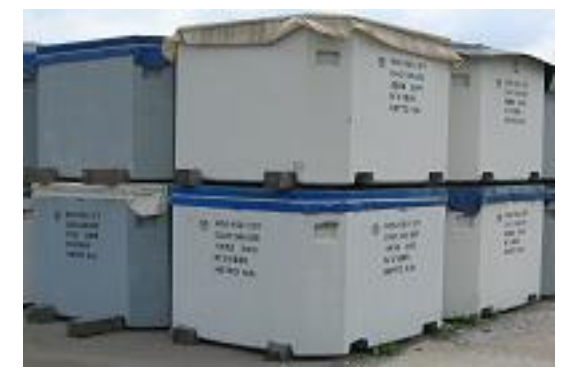

Fig. 1. The outer_view of NCPC-150-1,5P casks

The problem of the RW centralized storage is still unsolved in Ukraine. That is why the possibility to store the products of preprocessing the solid radioactive waste (SRW) and liquid radioactive waste (LRW) in the universal reinforced concrete protective cask (UCPC) is under consideration. It is supposed to place four barrels with a volume of 200 or 2801 containing compacted RW into the UCPC, therefore its inner volume is increased to $2.25 \mathrm{~m}^{3}$. As long as it is supposed to store compacted ash with a rather high activity, the UCPC walls are thicker than those of the NCPC, what makes $20 \mathrm{~cm}$ of concrete (see Table 1). 
Table 1 year. The averaged content of these isotopes for Properties of the reinforced concrete protective casks

\begin{tabular}{|c|c|c|}
\hline Name & $\begin{array}{c}\text { NCPC-150- } \\
1.5 \mathrm{P}\end{array}$ & $\begin{array}{c}\text { UCPC } \\
\text { (Ukraine) }\end{array}$ \\
\hline Capacity, $\mathrm{m}^{3}$ & 1.5 & 2.25 \\
\hline Wall thickness, cm & 15 & 20 \\
\hline $\begin{array}{c}\text { Overall dimen- } \\
\text { sions, cm }\end{array}$ & $165 \times 165 \times 137$ & $195 \times 195 \times 150$ \\
\hline
\end{tabular}

After placing of four primary barrels into the UCPC, the remaining free space inside this cask is filled with lightweight concrete with the density of $\sim 1.6 \mathrm{~g} / \mathrm{cm}^{3}$. This leads to a decrease in the level of gamma-radiation dose rate outside the UCPC and an improvement of safety while handling of the UCPC, i.e. when a cask falls down, the primary packages remain inside the cask and are not destroyed. The schematic view of the UCPC in which four primary packages are placed is presented in Fig. 2.

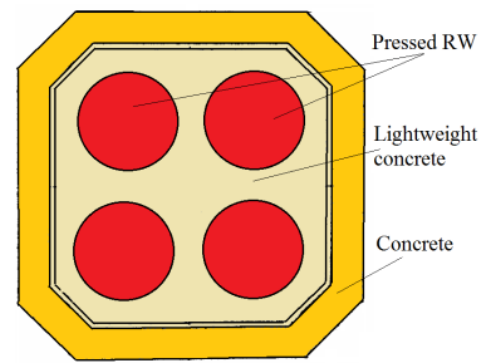

Fig. 2. Schematic of UCPC

It is supposed to provide an interim storage of the compacted RW in the storage facility on the NPP site area in a light-type hangar, where more than 1000 UCPCs are arranged in four tiers (Fig. 3.)

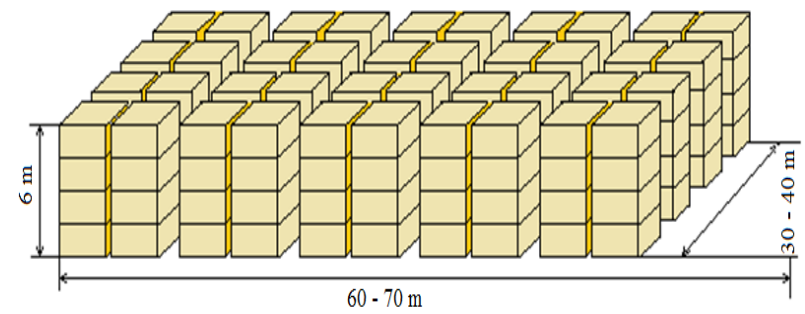

Fig. 3. Arrangement of UCPCs in four tiers

Consequently, the storage facility represents a source of radiation of large size (tens of meters), composed of "cubes" of UCPCs with different characteristics of the external radiation. The radiation features outside the cask are determined by the activity, spectral and elemental composition of the RW loaded into the primary packages.

To determine the thickness of the walls of the lighttype hangar storage, ensuring the radiation protection, and to determine the dose rates on personnel and the environment (both with biological shielding and without it) it is necessary to calculate the superposition of the radiation fields produced by the UCPCs arranged along the storage facility perimeter.

The following radionuclides determine more than $90 \%$ of the total activity of solid and liquid RW of the NPPs equipped with WWER reactors: ${ }^{54} \mathrm{Mn},{ }^{60} \mathrm{Co}$, ${ }^{110 \mathrm{~m}} \mathrm{Ag},{ }^{134} \mathrm{Cs},{ }^{137} \mathrm{Cs}$. Their half-life is more than half a

different types of RW is given in Table $2[2,3]$. From the above data it follows, that the RW isotopic composition significantly changes with an increase of storage time due to the decrease in the content of the isotopes with a short decay period. Taking into account the specific activity of the casks (RW is low or intermediate activity level), heating due to beta decay can be neglected $[4,5]$.

Table 2

Nuclide content in the salt melt, pressed SRW, and ash produced after burning of SRW and radioactive oil

\begin{tabular}{|c|c|c|c|c|c|c|}
\hline \multirow[b]{2}{*}{ \# } & \multirow[b]{2}{*}{ Isotope } & \multirow{2}{*}{$\begin{array}{c}\text { Average } \\
\text { energy } \\
\text { of } \gamma- \\
\text { quanta, } \\
\text { MeV }\end{array}$} & \multirow{2}{*}{$\begin{array}{l}\mathrm{T}_{1 / 2} \\
\text { year }\end{array}$} & \multicolumn{3}{|c|}{$\begin{array}{c}\text { Content of isotopes } \\
\chi_{j}, \% \\
\end{array}$} \\
\hline & & & & Ash & SRW & $\begin{array}{l}\text { Salt } \\
\text { melt }\end{array}$ \\
\hline 1 & ${ }^{54} \mathrm{Mn}$ & 0.83 & 0.858 & 24 & 28.60 & - \\
\hline 2 & ${ }^{60} \mathrm{Co}$ & 1.25 & 5.27 & 59 & 22.10 & 20 \\
\hline 3 & ${ }^{110 m} \mathrm{Ag}$ & 0.86 & 0.685 & - & 22.10 & - \\
\hline 4 & ${ }^{134} \mathrm{Cs}$ & 0.70 & 2.06 & 12 & 3.80 & 15 \\
\hline 5 & ${ }^{137} \mathrm{Cs}$ & 0.66 & 30 & 5 & 23.40 & 65 \\
\hline
\end{tabular}

After preprocessing, the density of the compacted RW reaches $\sim 3 \mathrm{~g} / \mathrm{cm}^{3}$ for SRW (SRW by $\sim 70 \%$ consists of concrete and contains up to $\sim 30 \%$ of iron), $2.2 \mathrm{~g} / \mathrm{cm}^{3}$ for the pressed ash, and from 1.7 to $2.1 \mathrm{~g} / \mathrm{cm}^{3}$ for the salt melt. The elemental composition of salt melt and ash is close to that of concrete.

\section{CALCULATION TECHNIQUE FOR RADIATION OUTSIDE THE UCPC CASKS}

In atomic energy, the gamma-radiation from vessels of various shape filled with RW are usually calculated using the method of volume integration of radiation point sources, which is realized in MicroShield [6] and VOLUME [7] codes. In our case, the biological shielding comprises the walls of the UCPC cask and lightweight concrete within the free space between the primary sources. Therefore, the biological shielding is characterized by a sufficiently large thickness. As a result, mentioned above codes cause a big error when calculating the characteristics of radiation in different directions around the UCPCs. Probably, this is due to the fact that the models in these codes have little in common with the real geometry of the UCPC.

At present, the characteristics of the external radiation from the sources with complex geometry are calculated with a high degree of accuracy by using the Monte Carlo method. Fig. 2 shows the geometric model of the reinforced concrete protective cask with four cylindrical sources of radiation, which was developed in the MCNP code [8]. The following radiation features are calculated at specified distances from the UCPC surface on the basis of this model: spectral composition, angular distribution, dose rate, etc. These radiation features are determined by the main RW isotopes: ${ }^{54} \mathrm{Mn}$, ${ }^{60} \mathrm{Co},{ }^{110 \mathrm{~m}} \mathrm{Ag},{ }^{134} \mathrm{Cs},{ }^{137} \mathrm{Cs}$. Such an approach makes it possible to determine these features subject to the specified initial isotopic composition of radionuclides in 
the radioactive waste, as well as the variation of these features depending on the storage time [9]. The distribution of the dose rate (DR), produced by the compacted RW (SRW), radionuclide ${ }^{60} \mathrm{Co}$, in the horizontal $(\mathrm{X}, \mathrm{Y})$ and vertical $(\mathrm{X}, \mathrm{Z})$ planes around the UCPC is shown in Fig. 4. The density of the compacted SRW, loaded into the primary packages with a volume of $280 \mathrm{l}$, is chosen to be $3 \mathrm{~g} / \mathrm{cm}^{3}$. Similar radiation features are calculated for the rest of the main isotopes: ${ }^{54} \mathrm{Mn},{ }^{110 \mathrm{~m}} \mathrm{Ag},{ }^{134} \mathrm{Cs},{ }^{137} \mathrm{Cs}$. The type of the DR dependencies for these isotopes is similar to that for

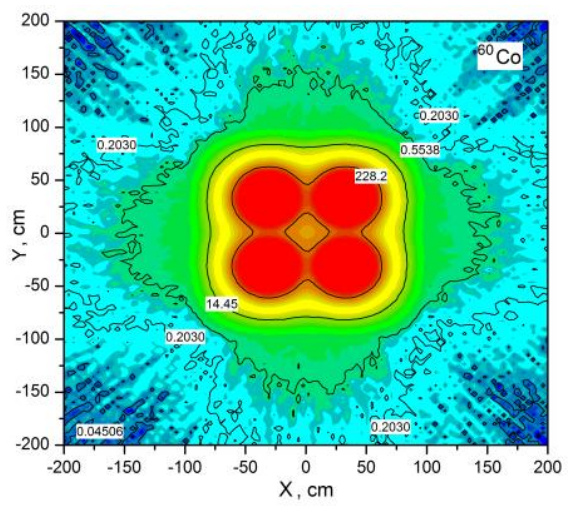

$a$
${ }^{60} \mathrm{Co}$. However, the DR values are lower due to the fact, that the average energy of $\gamma$-quanta, emitted by the radionuclides ${ }^{54} \mathrm{Mn},{ }^{110 \mathrm{~m}} \mathrm{Ag},{ }^{134} \mathrm{Cs},{ }^{137} \mathrm{Cs}$, is lower than the energy of ${ }^{60} \mathrm{Co} \gamma$-quanta (see Table 2). From the data given in Fig. 4 it follows, that the radiation spatial distribution around the UCPC is non-uniform in both horizontal and vertical planes. The spatial distribution of the radiation, produced by the UCPCs group, obviously depends on the relative position of the casks.

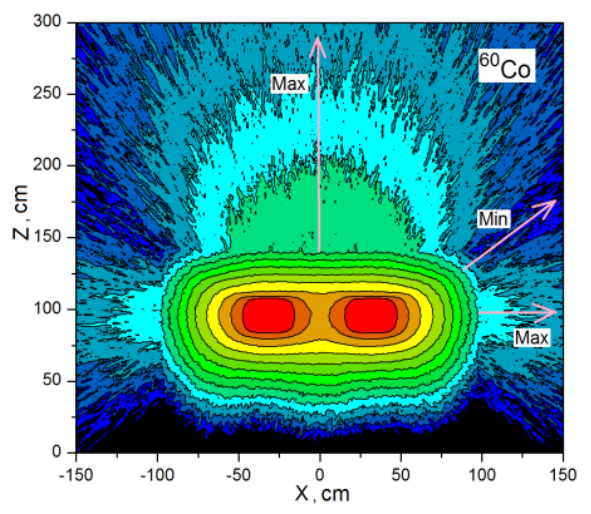

$b$

Fig. 4. DR distribution in the horizontal (a) and in the vertical (b) plane around the UCPC

In the following two main options for ensuring the radiation safety of the storage facility in which the UCPCs with RW are located at the NPP site or in the limited area, where the personnel, not engaged in the RW handling, can be present, are considered. The first option foresees building of a radiation protective wall (biological shielding). The second option foresees determining the size of the security zone and the installation of a disciplinary fence.

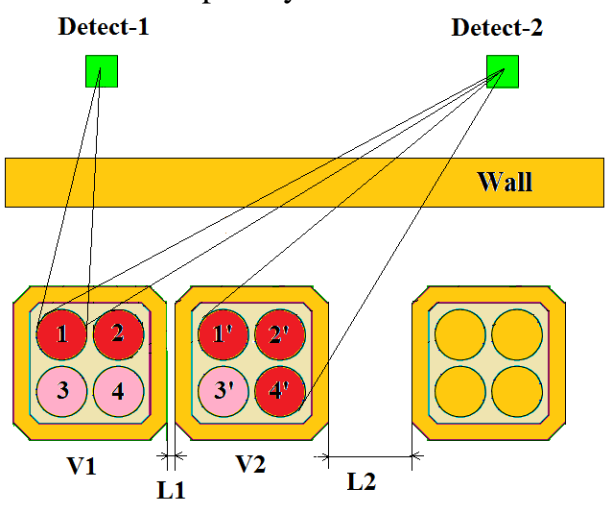

Fig. 5. Options of placing the UCPC in the horizontal plane

The personnel radiation safety requires that the dose rate does not exceed the allowable one at a certain distance from the radiation protective wall or at the security zone perimeter. It is obvious, that the largest contribution to the dose rate is made by the radiation sources located along the boundaries of the storage facility. Different options of the UCPC arrangement along the storage facility perimeter in the horizontal plane are shown in Fig. 5. At the distances between the casks $\mathrm{L} 1=10 \ldots 50 \mathrm{~cm}$, the DR is determined by RW placed in the primary packages $\left(1,2,1\right.$ ', $\left.2^{\prime}\right)$, which are nearest to Detect-1 and Detect-2. The radiation from the sources $(3,4,3$ ', 4') is considerably shielded by the primary packages $(1,2,1$ ', 2') filled with compacted RW of a rather high density and by an additional protection made of lightweight concrete. At the distances between the casks $\mathrm{L} 2=50 \ldots 100 \mathrm{~cm}$, the DR is increased due to the radiation from the source 4'. The UCPCs are arranged at the storage facility in four tiers. In the case of standard arrangement of the detectors at the height of $1 \mathrm{~m}$ from the ground level, at the distances comparable with the size of the cask, the maximum DR is produced by the casks, placed in the first tier. At the distances over $10 \mathrm{~m}$, the contribution to the DR of all tiers is almost the same.

Spatial distribution of the DR, produced by one UCPC at $\mathrm{L} 1=20 \mathrm{~cm}$, along the perimeter is determined for the following two options. First is the protective wall at the distance of $3 \mathrm{~m}$ from the UCPC, which is $40 \mathrm{~cm}$ thick wall of concrete with the density of $2.3 \mathrm{~g} / \mathrm{cm}^{3}$. The second is the security zone with the distance of $30 \mathrm{~m}$ from the UCPC. Here, the main radionuclides, contained in the SRW, are taken into account. The maximum DR from the UCPC is produced in both cases by ${ }^{60} \mathrm{Co}$ isotope, then, down going, by radionuclides: ${ }^{110 \mathrm{~m}} \mathrm{Ag},{ }^{134} \mathrm{Cs},{ }^{54} \mathrm{Mn},{ }^{137} \mathrm{Cs}$. The spatial distribution of the DR produced by one UCPC along the perimeter of the storage facility is shown in Fig. 6. Activity of radionuclides ${ }^{60} \mathrm{Co},{ }^{54} \mathrm{Mn}$, and ${ }^{137} \mathrm{Cs}$, is assumed to be $1 \mathrm{~Bq}$. Quantum yield for each isotope is taken into account. The DR distributions are normalized to the DR, produced by ${ }^{60} \mathrm{Co}$ radionuclide.

Presented in Fig. 6 distributions are used to calculate the total DR produced by UCPC arranged along the storage facility perimeter and filled with RW of different isotopic composition and activity. 


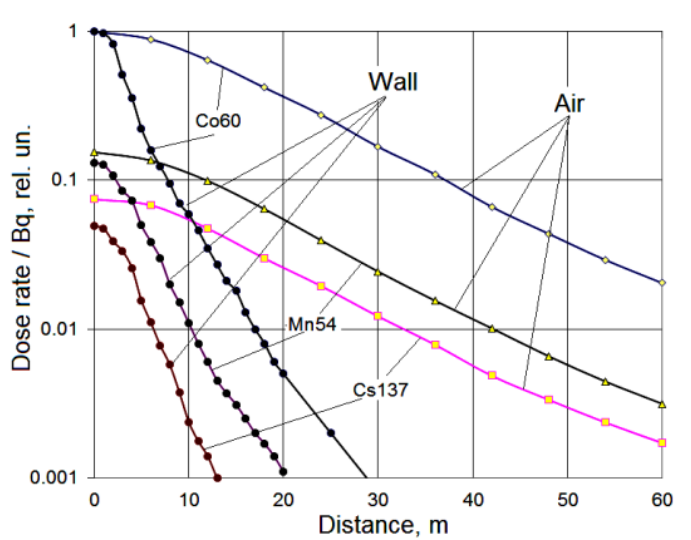

Fig. 6. Spatial distribution of DR produced by one $U C P C$ along the storage facility perimeter. Activity of ${ }^{60} \mathrm{Co},{ }^{54} \mathrm{Mn}$, and ${ }^{137} \mathrm{Cs}$ is $1 \mathrm{~Bq}$

The intermediate values of the DR dependences on the distance along the storage facility perimeter are determined by spline interpolation of discrete data, calculated in the MCNP code. The DR at the given distance from the casks arranged along the storage facility perimeter, produced by $i$-th isotope from one UCPC (in our case $i=1 \ldots 5$ for nuclides ${ }^{54} \mathrm{Mn},{ }^{60} \mathrm{Co}$, ${ }^{134} \mathrm{Cs},{ }^{137} \mathrm{Cs}$, ${ }^{110 \mathrm{~m}} \mathrm{Ag}$, respectively) with $1 \mathrm{~Bq}$ activity, is determined by spline function $D r_{\mathrm{i}}(\mathrm{x}), x$ coordinate is measured from the center of the cask. The DR from all $D r_{\mathrm{i}}(x)$ isotopes reads as:

$$
D R(x)=\sum_{\mathrm{i}} D r_{i}(x) \cdot A_{i},
$$

where $A_{i}$ is the activity of the $i$-th isotope contained in the UCPC.

The total DR at point $x$ along the storage facility, produced by $N$ casks arranged along the storage facility perimeter, is determined as follows:

$$
D \Sigma(x)=\sum_{J=1}^{N} D R\left(\left|x-X_{J}\right|\right) \cdot Q_{J}
$$

where $X_{J}$ is the coordinate of the $J$-th cask, $Q_{J}$ is the relative activity of the $J$-th cask if $D R(x)$ are the same, i.e. isotopic composition is identical, but the activities are different. Appropriate $D R(x)$ are used in the case of different RW isotopic compositions.

Since the UCPCs, loaded with RW, have different activities, then, by using the least square technique [10], which we developed earlier, it is possible to reduce the DR at the disciplinary fence of the security zone due to the optimal arrangement of casks along the storage facility perimeter. The solution of this problem is carried out by minimizing the mean-square deviation of DR from its average value at the distance of $0 \leq x \leq X p$ along the storage facility perimeter. The average value of DR reads as:

$$
\operatorname{Dav}=\frac{1}{X p} \cdot \sum_{J=1}^{N}\left[Q_{J} \cdot \int_{0}^{X_{p}} D R\left(\left|x-X_{J}\right|\right) d x\right] .
$$

The mean-square deviations of DR from their mean values are:

$$
\Delta=\int_{0}^{X p}\left[\sum_{J=1}^{N} D R\left(\left|x-X_{J}\right|\right) \cdot Q_{J}-D a v\right]^{2} d x .
$$

The mean-square deviation $\Delta$ reaches its minimum for the UCPC activity values $Q_{J}$, which are determined from the solution of the following system of $N$ linear equations:

$$
\frac{d \Delta}{d Q_{J}}=\left\{\int_{0}^{X p}\left[\sum_{J=1}^{N} D R\left(\left|x-X_{J}\right|\right) \cdot Q_{J}-D a v\right]^{2} d x\right\}=0 .
$$

The right-hand side of all $N$ linear equations with $Q_{J}$ unknown quantities is equal to zero, therefore the system of equations (5) has the trivial solution $Q_{J}=0$. Since the sum of all the UCPC activities $Q_{J}$ is nonzero, then the sequential addition of the equation $\sum_{J=1}^{N} Q_{J}=$ const instead of one of the $N$ linear equations of system (5) results in a system of equations having a non-trivial solution.

In [1], it was proposed to arrange the primary packages with RW with a shift towards one of the corners of the NCPC cask (asymmetric loading) (Fig. 7). In this case the DR from two faces of the filled NCPC cask decreases. To reduce the DR we propose to load two UCPC casks asymmetrically and to arrange them in pairs on the storage facility perimeter (see Fig. 7).

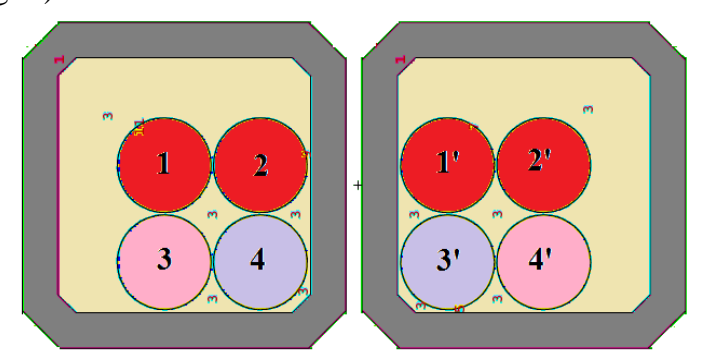

Fig. 7. Asymmetric arrangement of the UCPC and their mirror placement in pairs along the storage perimeter

\section{NUMERICAL RESULTS}

The radiation from the casks arranged in four tiers has been calculated for two options: with a protective wall and with a security zone (see Fig. 6). Dose rates as a function of the distance along the storage facility are determined with account for the partial contribution of radionuclides in accordance with the SRW isotopic composition in the form of splines (see Table 2). The spatial distribution of the DRs produced by 27 rows of the UCPCs arranged in four tiers, along the storage facility, at the distance of $1 \mathrm{~m}$ from the protective wall (at the height of $1 \mathrm{~m}$ from the ground, $40 \mathrm{~cm}$ thick wall of concrete) is presented in Fig. 8. The DR maximum value for the option under consideration is equal to one. The activity of four-tier cask block placed at the perimeter is assumed to be $Q_{J}=1$ (curve Identical $Q=1$ ). Correspondingly, the sum of the activities along the row is 27 . Optimal values of the activities $Q_{J}$ are determined from the eqs. (2)-(5) and the condition, that the sum of the activities is equal to 27. These values are presented by the curve Wall in Fig. 11. The difference between the spatial distribution of the DR, produced by the casks with optimum activities (see curve Optimum activities in Fig. 8), and that of the DR from the casks with the same activity is quite insignificant (less than $3.5 \%$ ). This is due to the rapid decrease of the DR produced by a single container. The DR from one UCPC is shown in Fig. 8 for containers No. 6, 11, 19, 
and 27, whose activities are equal to $1,0.8,1.1$, and 1.3, respectively.

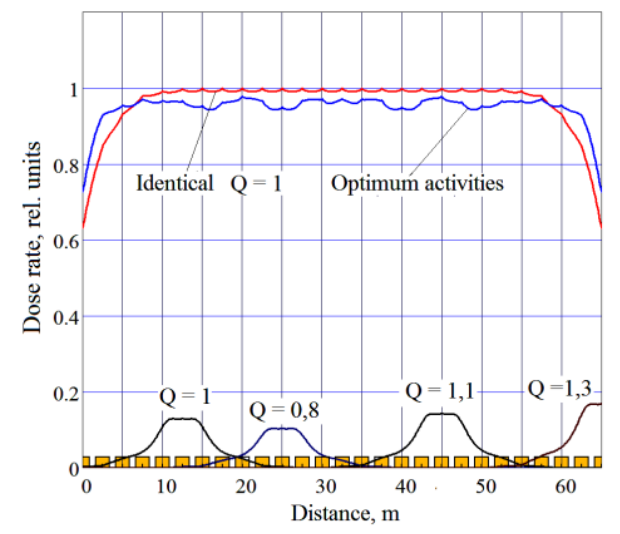

Fig. 8. Spatial distribution of the DR produced by 28 rows of UCPC along the storage facility at the distance of $1 \mathrm{~m}$ from the protective wall

To calculate the radiation from casks on the disciplinary fence of the security zone without a protective wall, the arrangement of four-tier blocks in pairs along the perimeter of the storage facility is considered. This scheme allows comparing the DR with both symmetric (see Fig. 5) and asymmetric (see Fig. 7) loading of the UCPC. The arrangement of UCPCs in pairs assumes the distance between the casks in a pair $\mathrm{L} 1=10 \mathrm{~cm}$, and between the pairs of casks $\mathrm{L} 2=$ $100 \mathrm{~cm}$. Fig. 9 shows the DR at the distance of $30 \mathrm{~m}$, produced by one UCPC with the symmetric and asymmetric cask loading, subject to the distance along the storage facility. The DR is calculated with the partial contribution of radionuclides with account for the SRW isotopic composition (see Table 2).

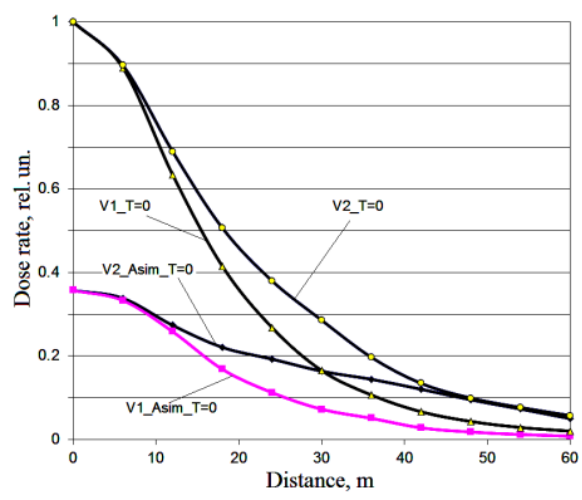

Fig. 9. Dependencies of the spline functions of the DR from one UCPC on the distance along the storage facility. Symmetric and asymmetric cask loading

From the above data it follows, that due to the radiation shielding by the neighboring cask (see option V1 Fig. 5), the DR at greater distances in this case is lower than for the option V2.

The spatial distribution of the DRS, produced by 27 rows of UCPC in four tiers, along the storage facility, are calculated for the asymmetric and symmetric cask loading using the data presented in Fig. 9. For the symmetric loading of the UCPC, the optimum values of the $Q_{J}$ activities (see curve Air in Fig. 11) are determined using the ratios (2)-(5) and the condition, that the sum of the cask activities is 27 . The spatial distribution of the DR along the storage facility at the distance of $30 \mathrm{~m}$ from the UCPCs arranged along perimeter is shown in Fig. 10.

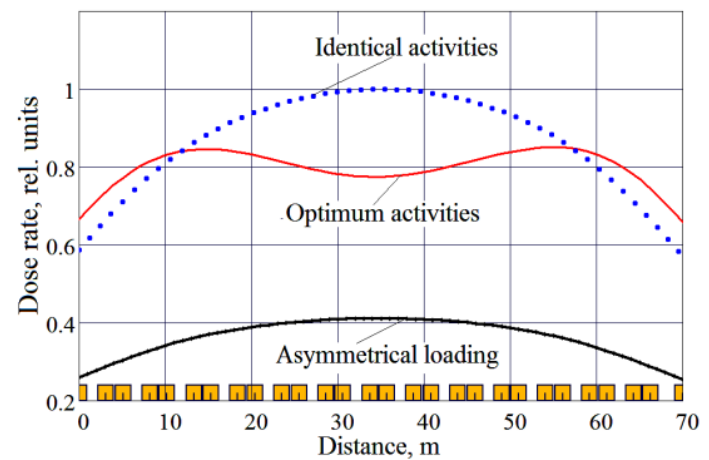

Fig. 10. The spatial distribution of the DR along the storage facility, produced by 27 rows of the UCPCs arranged along the perimeter at the distance of $30 \mathrm{~m}$ from the storage facility perimeter

From the above data it follows that the arrangement of the casks along the storage facility perimeter with the optimal distribution of activities taken into account allows reducing the DR maximum value on the disciplinary fence of the security zone by $\sim 20 \%$. The asymmetric loading of the UCPC with primary cylindrical barrels filled with compacted SRW reduces the DR at the disciplinary fence by $\sim 2.5$ times as compared to the symmetrical, and by 2 times as compared to the optimal loading.

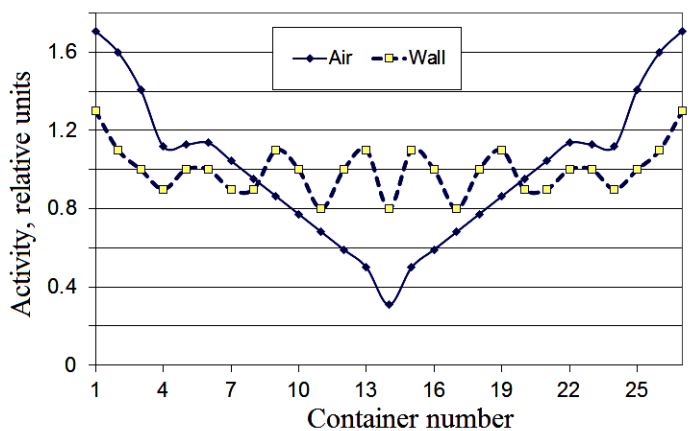

Fig. 11. The optimum values of $Q_{J}$ activities for protective wall and for the security zone (curve Air)

\section{CONCLUSIONS}

The technique is developed to calculate the external radiation from a large-size source consisting of dozens of radiating elements of the same geometry. The radiating elements have the shape of concrete rectangular cask into which cylindrical barrels filled with compacted SRW are loaded. The Monte Carlo method is used to calculate the spatial characteristics of the radiation around the casks, produced by the definite RW radionuclides, for different options of their arrangement. Shielding by neighboring casks and presence of an additional biological shielding is taken into account.

The storage facilities are considered to be arranged in the following way. More than one hundred casks are assumed to be arranged in four tiers along the perimeter of the storage facility. The DRs for these facilities are determined using the data obtained by Monte Carlo method. If the concrete casks with the same activity are 
arranged along the perimeter of the storage facilities, the DR along the perimeter of the storage facility with biological shielding is shown to be almost uniform. For the storage facility without shielding the DR has the shape of an inverted parabola with its maximum in the center. The DRs along the perimeter of the storage area is minimized via variation of radiation rate from different casks. For the storage without protection, the arrangement of the sources with optimized activities reduces the DR by $\sim 20 \%$. For the storage facility with biological shielding, such an arrangement causes negligible effect on the DR. The latter decreases only by $\sim 3.5 \%$. The most efficient method of reducing the DR from a large-sized storage facility is a combination of two actions. First, the casks should be arranged in pairs with mirror placement along the perimeter of the cask storage facility. Second, the primary barrels with RW should be loaded into the casks with a shift towards one of the corners (asymmetric loading). This method reduces the $\mathrm{DR}$ by $\sim 2.5$ times.

\section{REFERENCES}

1. S.V. Rosnovsky, S.K. Buns. Methodology conditioning of radioactive waste solidification using the NZK casks with the storage containers in the lungs storage hangar type // Proceedings of the 8th International Scientific and Technical Conference "Safety Assurance of NPP with WWER", 28-31 May 2013, Podolsk.

http://www.pandia.ru/text/78/544/38829-6.php

2. Y.V. Rudychev. Determination of external irradiation from sources with complex geometry containing radioactive waste // East Eur. J. Phys. 2016, v. 3, N 1, p. 35-40.

3. V.G. Rudychev, I.O. Girka, Y.V. Rudychev, et al. Change of radioactive waste characteristics at their processing and storage at nuclear power plants //
Problems of Atomic Science and Technology. Series "Nuclear Physics Investigations" (64). 2015, N 3(97), p. 83-88.

4. V.G. Rudychev, M.O. Azarenkov, I.O. Girka, Y.V. Rudychev, O.P. Shchus. Contribution of radionuclides to heat release in the process of SNF dry storage // Problems of Atomic Science and Technology. Series "Physics of Radiation Effect and Radiation Materials Science” (109). 2017, N 2(108), p. 91-96.

5. S. Alyokhina. Thermal Analysis of Certain Accident Conditions of the Dry Spent Nuclear Fuel Storage // Nuclear Engineering and Technology. 2018, v. 50, issue 5, p. 717-723; DOI: 10.1016/j.net.2018.03.002/

6. http://radiationsoftware.com/microshield/

7. S. Pismenetskiy, V. Rudychev, Y. Rudychev, O.K. Tutunik. Analysis of external gamma-ray from a cylinder tank filled with radioactive wastes // The Journal of Kharkov National University. Physical series "Nuclei, Particles, Fields". 2008, v. 808, issue 2/38/, p. 53-60.

8. X-5 Monte-Carlo Team. MCNP-A General Monte-Carlo N-Particle Transport Code. Version 5. Volume I: Overview and Theory. USA: Los Alamos National Laboratory, 2003, LA-UR-03-1987.

9. V.G. Rudychev, N.A. Azarenkov, I.A. Girka, Y.V. Rudychev. Efficiency of the dose rate calculation by Monte-Carlo method and point kernel method when handling radioactive waste // Problems of Atomic Science and Technology. Series "Physics of Radiation Effect and Radiation Materials Science” (112). 2018, N 2(114), p. 63-69

10. V.G. Rudychev, N.A. Azarenkov, I.A. Girka, Y.V. Rudychev. Irradiation Dose Minimization by Optimizing the Arrangement of Radiation Sources of Different Intensity // Atomic Energy. 2016, v. 119, issue 4, p. 285-290.

\title{
КОМБИНИРОВАННЫЙ РАСЧЕТ ИЗЛУЧЕНИЙ ОТ ПОВЕРХНОСТНЫХ ХРАНИЛИЩ РАО БОЛЬШИХ РАЗМЕРОВ НА ОСНОВЕ МЕТОДА МОНТЕ-КАРЛО
}

\author{
В.Г. Рудычев, Н.А. Азаренков, И.А. Гирка, Д.В. Рудычев, Е.В. Рудычев
}

Разработана методика уменьшения дозовых нагрузок, создаваемых приповерхностными источниками излучений больших размеров, на периметре которых находятся десятки излучающих элементов одинаковой геометрии. Излучающие элементы представляют собой бетонные прямоугольные контейнеры, в которых размещены цилиндрические емкости с прессованными РАО. Выполнены расчеты пространственных характеристик излучения методом Монте-Карло вокруг контейнера, создаваемого отдельными радионуклидами РАО, с учетом экранирования соседними контейнерами при разных вариантах их размещения, а также наличия дополнительной биозащиты.

\section{КОМБІНОВАНИЙ РОЗРАХУНОК ВИПРОМІНЮВАНЬ ВІД ПОВЕРХНЕВИХ СХОВИЩ РАВ ВЕЛИКИХ РОЗМІРІВ НА ОСНОВІ МЕТОДУ МОНТЕ-КАРЛО}

\author{
В.Г. Рудичев, М.О. Азаренков, І.О. Гірка, Д.В. Рудичев, С.В. Рудичев
}

Розроблено методику зменшення дозових навантажень, створюваних приповерхневими джерелами випромінювань великих розмірів, на периметрі яких знаходяться десятки випромінюючих елементів однакової геометрії. Випромінюючі елементи являють собою бетонні прямокутні контейнери, в яких розміщені циліндричні ємності з пресованими РАВ. Виконано розрахунки просторових характеристик випромінювання методом Монте-Карло навколо контейнера, створюваного окремими радіонуклідами РАВ, з урахуванням екранування сусідніми контейнерами при різних варіантах їх розміщення, а також наявності додаткового біозахисту. 